\title{
Duganella violaceinigra sp. nov., a novel mesophilic bacterium isolated from forest soil
}

\author{
Correspondence \\ Chang-Jin Kim \\ changjin@kribb.re.kr or \\ liact@hotmail.com
}

\author{
Wen-Jun Li, ${ }^{1,2} \uparrow$ Yu-Qin Zhang, ${ }^{2} \dagger$ Dong-Jin Park, ${ }^{1}$ Chang-Tian Li, ${ }^{1}$ \\ Li-Hua Xu, ${ }^{2}$ Chang-Jin Kim ${ }^{1}$ and Cheng-Lin Jiang ${ }^{2}$
}

\begin{abstract}
${ }^{1}$ Korea Research Institute of Bioscience and Biotechnology, 52 Oeundong, Yusong, Daejeon 305-333, Republic of Korea

${ }^{2}$ The Key Laboratory for Microbial Resources of the Ministry of Education, People's Republic of China, Laboratory for Conservation and Utilization of Bio-Resources, Yunnan Institute of Microbiology, Yunnan University, Kunming, Yunnan 650091, People's Republic of China
\end{abstract}

The genus Duganella was first proposed by Hiraishi et al. (1997) as a reclassification of a misnamed strain, IAM $12670^{\mathrm{T}}$ ( = ATCC $25935^{\mathrm{T}}$ ), which was defined as a Gramnegative, obligately aerobic, chemo-organotrophic, nonspore-forming, rod-shaped bacterium with flagella. At present, the genus comprises only one species, Duganella zoogloeoides.

During our screening research on the microbial flora of Yunnan, China, strain YIM $31327^{\mathrm{T}}$ was recovered on $\mathrm{HV}$ agar (Hayakawa \& Nonomura, 1987) and then investigated using a polyphasic taxonomic approach. HV agar medium contained the following (in 1 litre distilled water, final pH 7.2): humic acid, $1.0 \mathrm{~g} ; \mathrm{KCl}, 1.7 \mathrm{~g} ; \mathrm{Na}_{2} \mathrm{HPO}_{4}, 0.5 \mathrm{~g}$; $\mathrm{MgSO}_{4} .7 \mathrm{H}_{2} \mathrm{O}, 0.5 \mathrm{~g} ; \mathrm{CaCO}_{3}, 0.02 \mathrm{~g} ; \mathrm{FeSO}_{4} .7 \mathrm{H}_{2} \mathrm{O}, 0.01 \mathrm{~g}$; $\mathrm{B}$ vitamins $(0.5 \mathrm{mg}$ each of thiamin, riboflavin, niacin, pyridoxin, calcium D-pantothenate, inositol, $p$-aminobenzoic acid and $0.25 \mathrm{mg}$ biotin); cycloheximide, $50 \mathrm{mg}$; nalidixic acid, $20 \mathrm{mg}$; agar, $15 \cdot 0 \mathrm{~g}$.

The strain was maintained on a YM (yeast extract/malt extract) agar slant at $4{ }^{\circ} \mathrm{C}$ and as $20 \%$ (w/v) glycerol suspensions at $-20^{\circ} \mathrm{C}$. Biomass for chemical and molecular

†These authors contributed equally to the work.

The GenBank/EMBL/DDBJ accession number for the 16S rRNA gene sequence of strain YIM $31327^{\top}$ is AY376163. studies was obtained by cultivation, in shake flasks (at about 150 r.p.m.), with YM broth at $28^{\circ} \mathrm{C}$ for 1 week.

Strain YIM $31327^{\mathrm{T}}$ was grown on YM agar for observation of the cellular and colony morphology, and on some other media as controls, e.g. nutrient agar, trypticase/soy agar and Mueller-Hinton agar. Strain YIM $31327^{\mathrm{T}}$ exhibited either weak growth or no growth on the media tested, except on YM agar. Yeast extract and the vitamin mixture of $\mathrm{HV}$ medium could stimulate its growth. No diffusible pigments were produced on any media. Morphological characteristics of strain YIM $31327^{\mathrm{T}}$ were observed under light microscopy (model BH 2; Olympus) and using an electron microscope (JEM-1010; JEOL) after 1 week of growth on YM agar. The cells of strain YIM $31327^{\mathrm{T}}$ were short, rod-shaped, motile, non-spore-forming and possessed flagella; they were about $0 \cdot 4-0 \cdot 6 \mu \mathrm{m}$ wide and $0 \cdot 8-1 \cdot 0 \mu \mathrm{m}$ long and occurred singly (Fig. 1). Colonies reached a maximum size $(5-8 \mathrm{~mm}$ in diameter) after 1 week of incubation at $28^{\circ} \mathrm{C}$ and were violet-black in colour and circular.

Gram-staining was carried out with 48 h cultures. Catalase activity was determined by means of the production of bubbles after the addition of a drop of $3 \% \mathrm{H}_{2} \mathrm{O}_{2}$. All physiological and biochemical tests were performed at $28^{\circ} \mathrm{C}$. Tests for carbon-source utilization, sugar fermentation and enzymes (qualitative) were carried out using API ID 32E, API 20NE and API 50CH test kits (bioMérieux). Strain YIM $31327^{\mathrm{T}}$ was found to be Gram-negative and 

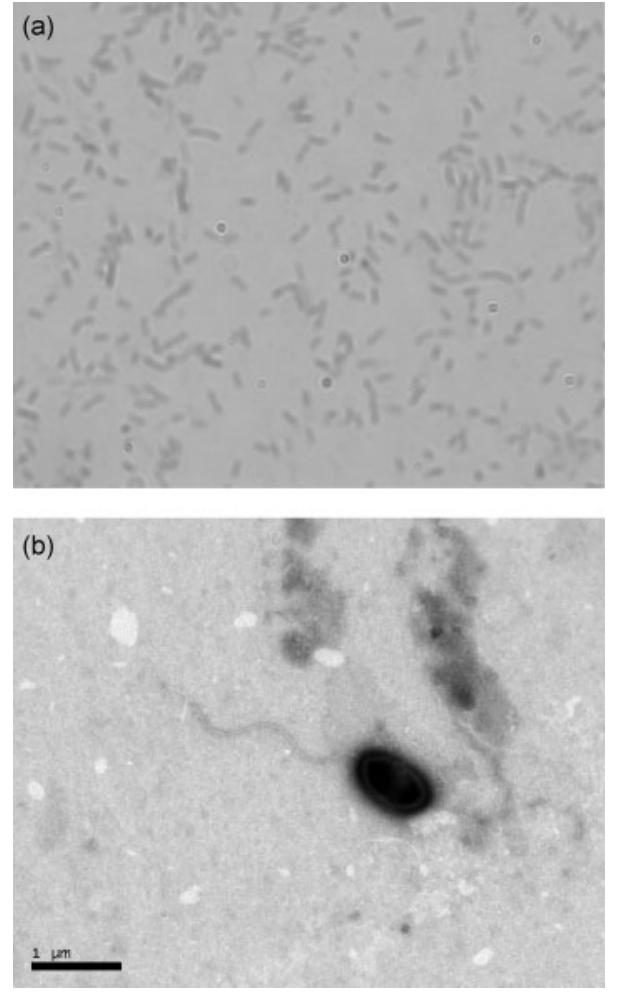

Fig. 1. Light micrograph (a) and scanning election micrograph (b) of strain YIM $31327^{\top}$ grown on YM agar for 1 week at $28^{\circ} \mathrm{C}$. Bar, $1 \mu \mathrm{m}(\mathrm{b})$.

obligately aerobic. The results of other phenotypic test are provided below in the description of the novel species and in Table 1.

The ubiquinones were isolated using the methods of Minnikin et al. (1984) and separated by HPLC (Kroppenstedt, 1982). The cellular fatty acid composition was determined as described by Sasser (1990) using the
Microbial Identification System (MIDI). The ubiquinones were Q-8 (94\%) and Q-7 (6\%). The major fatty acids were $\mathrm{C}_{16: 0}(29 \cdot 4 \%), \mathrm{C}_{12: 0}(13 \cdot 6 \%), 3-\mathrm{OH} \mathrm{C} 10: 0(5 \cdot 1 \%), 3-\mathrm{OH}$ $\mathrm{C}_{12: 0}(7 \cdot 6 \%), 2-\mathrm{OH} \mathrm{C} \mathrm{C}_{12: 0}(5 \cdot 7 \%), \mathrm{C}_{14: 0}(1 \cdot 2 \%), \mathrm{C}_{10: 0}$ $(1 \cdot 0 \%), \mathrm{C}_{18: 1 \omega 7 c}(3.3 \%)$ and summed feature 3 , which comprises $\mathrm{C}_{16: 1 \omega 7 c}$ or $2-\mathrm{OH}$ i- $\mathrm{C}_{15: 0}(32 \cdot 6 \%)$ or both.

Extraction of genomic DNA and amplification of the $16 \mathrm{~S}$ rRNA gene were done as described by $\mathrm{Xu}$ et al. (2003). Phylogenetic analysis was performed using the software packages PHYLIP (Felsenstein, 1993) and MEGA (Molecular Evolutionary Genetics Analysis) version 2.1 (Kumar et al., 2001) after multiple alignment of data by CLUSTAL_X (Thompson et al., 1997). Distances (distance options according to the Kimura two-parameter model) (Kimura, 1980, 1983) were calculated and clustering was performed with the neighbour-joining method (Saitou \& Nei, 1987). Bootstrap analysis was used to evaluate the tree topology of the neighbour-joining data by means of 1000 resamplings (Felsenstein, 1985).

Genomic DNA of strain YIM $31327^{\mathrm{T}}$ for $\mathrm{G}+\mathrm{C}$ content determination was prepared according to the method of Marmur (1961). The G $+\mathrm{C}$ content, determined using the thermal denaturation method of Marmur \& Doty (1962), was $62 \cdot 8 \mathrm{~mol} \%$.

The almost-complete 16S rRNA gene sequence (1439 bp) of strain YIM $31327^{\mathrm{T}}$ was determined. A neighbour-joining tree, generated between positions 56 and 1478 (Escherichia coli positions; Brosius et al., 1978), is shown in Fig. 2. The sequence of strain YIM $31327^{\mathrm{T}}$ was closest to that of D. zoogloeoides IAM $12670^{\mathrm{T}}(96 \cdot 73 \%$ similarity), and the two strains formed a distinct branch in the phylogenetic tree (Fig. 2).

Similarities in morphological characteristics, ubiquinone and fatty acid compositions and $\mathrm{G}+\mathrm{C}$ content support the inclusion of strain YIM $31327^{\mathrm{T}}$ in the genus Duganella (Hiraishi et al., 1997), i.e. both strain YIM $31327^{\mathrm{T}}$ and

Table 1. Differential phenotypic characteristics of strain $\mathrm{YIM} 31327^{\top}$ and its closest phylogenetic relative, D. zoogloeoides IAM $12670^{\top}$

Data for D. zoogloeoides were taken from Hiraishi et al. (1997). +, Present; -, absent.

\begin{tabular}{|c|c|c|}
\hline Characteristic & D. violaceinigra $\mathrm{YIM} 31327^{\mathrm{T}}$ & D. zoogloeoides IAM $12670^{\mathrm{T}}$ \\
\hline Growth on nutrient agar & - & + \\
\hline Colour of non-diffusible pigment & Violet-black & Yellow \\
\hline Oxidative acid produced from glucose & - & + \\
\hline Hydrolysis of starch & - & + \\
\hline Urease & - & + \\
\hline Oxidase & - & + \\
\hline Major cellular fatty acids & $\mathrm{C}_{16: 0}, \mathrm{C}_{12: 0}$ & $\mathrm{C}_{16: 0}, \mathrm{C}_{16: 1}$ \\
\hline Major hydroxy fatty acids & $3-\mathrm{OH} \mathrm{C} \mathrm{C}_{10: 0}, 3-\mathrm{OH} \mathrm{C}_{12: 0}, 2-\mathrm{OH} \mathrm{C}_{12: 0}$ & $3-\mathrm{OH} \mathrm{C} 10: 0$ \\
\hline DNA G $+\mathrm{C}$ content $(\mathrm{mol} \%)$ & $62 \cdot 8$ & $63-64$ \\
\hline
\end{tabular}




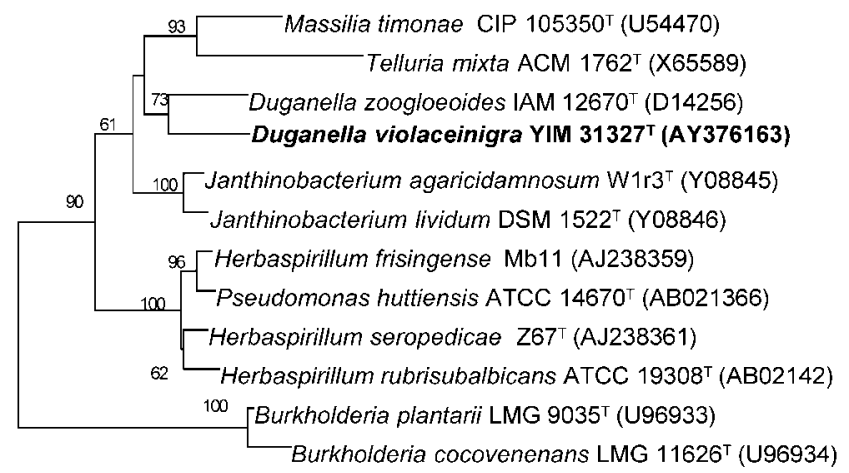

0.02

Fig. 2. Phylogenetic dendrogram, based on $16 \mathrm{~S}$ rRNA gene sequence analysis, constructed using the neighbour-joining method, showing the phylogenetic position of strain YIM $31327^{\top}$ within the genus Duganella. The sequence of $E$. coli was used as the outgroup (not shown). Scale bar, inferred nucleotide substitution per 100 nucleotides.

D. zoogloeoides IAM $12670^{\mathrm{T}}$ show flagellation and flocculent growth, have no diffusible pigments, possess gelatinase and catalase, and have Q-8 as the major respiratory quinone. However, strain YIM $31327^{\mathrm{T}}$ differs from the only recognized species of the genus Duganella by the absence of oxidase activity, the inability to hydrolyse starch, the fact that no oxidative acid is produced from glucose, and by the scarce or non-existent growth on nutrient agar. In addition, the non-diffusible pigment of strain YIM $31327^{\mathrm{T}}$ is violet-black in colour, while that of D. zoogloeoides IAM $12670^{\mathrm{T}}$ is yellow.

Thus, on the basis of the above phenotypic and genotypic data, we consider strain YIM $31327^{\mathrm{T}}$ to represent a novel species of the genus Duganella, for which we propose the name Duganella violaceinigra sp. nov.

\section{Description of Duganella violaceinigra sp. nov.}

Duganella violaceinigra (vi.o.la.ce.i.ni'gra. L. adj. violaceus - a -um violet; L. adj. niger -gra -grum black; N.L. fem. adj. violaceinigra violet-black, after the colour of the colonies).

Cells are obligately aerobic, Gram-negative, non-sporeforming, short and rod-shaped with flagella, about $0 \cdot 4$ $0 \cdot 6 \times 0 \cdot 8-1 \cdot 0 \mu \mathrm{m}$ in size and occur singly. The cells produce flocculant growth in YM broth and the colonies on YM agar plates are wrinkled and a little leathery. Catalase activity is present, whereas oxidase activity is absent. Hydrolyses gelatin and aesculin. Unable to reduce nitrate or denitrify. Utilizes D-glucose, D-cellobiose, xylose, mannitol, galactose, maltose, lactose, salicin and $N$-acetyl- $\beta$-glucosamine as sole carbon sources, but unable to utilize glycerol, erythritol, D-ribose or fructose. Alkaline phosphatase, esterase, esterase lipase, lipase, $\alpha$-glucoside, $\beta$-glucoside, leucine arylamidase, acid phosphatase and naphthol-AS-BI-phosphohydrolase are present, whereas valine arylamidase, cystine arylamidase, trypsin, $\alpha$-chymotrypsin, $\alpha$-galactosidase, $\beta$-galactosidase, $\beta$-glucuronidase, $N$-acetyl- $\beta$-glucosaminidase, $\alpha$-mannosidase, $\alpha$-fucosidase, urease, arginine dihydrolase and indole production are not. The major ubiquinone is Q-8 and the major cellular fatty acids are $\mathrm{C}_{16: 0}(29 \cdot 4 \%)$ and $\mathrm{C}_{12: 0}$ $(13 \cdot 6 \%) ; 3-\mathrm{OH} \mathrm{C} 10: 0(5 \cdot 1 \%), 3-\mathrm{OH} \mathrm{C} \mathrm{C}_{12: 0}(7 \cdot 6 \%)$ and $2-\mathrm{OH} \mathrm{C}_{12: 0}(5 \cdot 7 \%)$ are the major hydroxy fatty acids. The optimum growth temperature is $28-30{ }^{\circ} \mathrm{C}$ and the optimum $\mathrm{pH}$ for growth is $7 \cdot 2$. The DNA $\mathrm{G}+\mathrm{C}$ content is $62 \cdot 8 \mathrm{~mol} \%$. Isolated from a forest soil sample in Yunnan Province, China.

The type strain is YIM $31327^{\mathrm{T}}\left(=\mathrm{CIP} 108077^{\mathrm{T}}=\mathrm{KCTC}\right.$ $\left.12193^{\mathrm{T}}\right)$.

\section{Acknowledgements}

We are grateful to Professor Dr H. G. Trüper for the Latin construction of the species name. This research was supported by the Chinese National Natural Science Foundation (30270004) and the 21C Frontier Microbial Genomics and Application Centre Program, Ministry of Science and Technology (MG02-0101-002-1-0-0), and the International Cooperation R \& D Program, Ministry of Science and Technology (M6-0203-00-0002), Korea.

\section{References}

Brosius, J., Palmer, M. L., Kennedy, P. J. \& Noller, H. F. (1978). Complete nucleotide sequence of a $16 \mathrm{~S}$ ribosomal RNA gene from Escherichia coli. Proc Natl Acad Sci U S A 75, 4801-4805.

Felsenstein, J. (1985). Confidence limits on phylogenies: an approach using the bootstrap. Evolution 39, 783-791.

Felsenstein, J. (1993). PHYLIP (phylogeny inference package), version 3.5c. Department of Genetics, University of Washington, Seattle, USA.

Hayakawa, M. \& Nonomura, H. (1987). Humic acid-vitamin agar, a new medium for the selective isolation of soil actinomycetes. J Ferment Technol 65, 501-509.

Hiraishi, A., Shin, Y. K. \& Sugiyama, J. (1997). Proposal to reclassify Zoogloea ramigera IAM 12670 (P. R. Dugan 115) as Duganella zoogloeoides gen. nov., sp. nov. Int J Syst Bacteriol 47, 1249-1252.

Kimura, M. (1980). A simple method for estimating evolutionary rates of base substitutions through comparative studies of nucleotide sequences. J Mol Evol 16, 111-120.

Kimura, M. (1983). The Neutral Theory of Molecular Evolution. Cambridge: Cambridge University Press.

Kroppenstedt, R. M. (1982). Separation of bacterial menaquinones by HPLC using reverse phase (RP 18) and a silver loaded ion exchanger as stationary phases. J Liquid Chromatogr 5, 2359-2387.

Kumar, S., Tamura, K., Jakobsen, I. B. \& Nei, M. (2001). MEGA2: Molecular Evolutionary Genetics Analysis software. Bioinformatics 17, 1244-1245.

Marmur, J. (1961). A procedure for the isolation of deoxyribonucleic acid from microorganisms. J Mol Biol 3, 208-218.

Marmur, J. \& Doty, P. (1962). Determination of base composition of deoxyribonucleic acid from its denaturation temperature. $J$ Mol Biol 5, 109-118.

Minnikin, D. E., O'Donnell, A. G., Goodfellow, M., Alderson, G., Athalye, M., Schaal, A. \& Parlett, J. H. (1984). An integrated 
procedure for the extraction of isoprenoid quinones and polar lipids. J Microbiol Methods 2, 233-241.

Saitou, N. \& Nei, M. (1987). The neighbor-joining method: a new method for reconstructing phylogenetic trees. Mol Biol Evol 4, 406-425.

Sasser, M. (1990). Identification of bacteria by gas chromatography of cellular fatty acids. USFCC Newsl 20, 16.
Thompson, J. D., Gibson, T. J., Plewniak, F., Jeanmougin, F. \& Higgins, D. G. (1997). The CLUSTAL_X windows interface: flexible strategies for multiple sequence alignment aided by quality analysis tools. Nucleic Acids Res 25, 4876-4882.

Xu, P., Li, W. J., Xu, L. H. \& Jiang, C. L. (2003). A microwave-based method for genomic DNA extraction from Actinomycetes. Microbiology (Beijing) 30, 73-75. 